\title{
Maria Borejszo
}

Uniwersytet im. Adama Mickiewicza w Poznaniu

\section{Świat ptaków w staropolskich kolędach i pastorałkach (na materiale Kantyczek karmelitańskich z XVII i XVIII wieku)}

Stajenka betlejemska kojarzy się nam współcześnie najczęściej z nowo narodzonym Jezusem, Maryją, Józefem oraz zwierzętami - wołem i osłem, a także z postaciami pasterzy, ich owiec i mędrców ze Wschodu. Obraz ten został wykreowany i rozpowszechniony już w średniowiecznej Europie, głównie przez zakon franciszkanów, dzięki nim dotarł również na ziemie polskie ${ }^{1}$. W staropolskich kolędach, wykorzystujących nie tylko przekazy ewangeliczne, ale też bardzo popularną w Europie twórczość apokryficzną i ludowă, obraz ten został rozbudowany i uszczegółowiony o dodatkowe elementy świata przedstawionego. Jednym z nich są ptaki, wyrażające swą radość z powodu narodzin Zbawiciela. Motyw ten dość często pojawia się w dawnych polskich pieśniach i scenkach dialogowanych opartych na wątkach bożonarodzeniowych, warto więc poświęcić mu nieco uwagi.

Bogatego i różnorodnego materiału badawczego dostarcza tu przede wszystkim twórczość kolędowa czasów baroku i oświecenia, ze względu na jej rodzimy charakter i oryginalność. Nowe prądy w liryce religijnej, zapocząt-

\footnotetext{
${ }^{1}$ Pierwszą wzmiankę o bożonarodzeniowych szopkach budowanych w kościołach franciszkańskich na ziemiach polskich znajdujemy w Życiu i obyczajach Grzegorza z Sanoka autorstwa Filipa Kallimacha z 1476 roku (por. P. Callimachi, Vita et mores Gregorii Sanocei, wyd., przeł. J. Lichońska, Warszawa 1963, s. 63), natomiast najstarsze zachowane figurki jasełkowe pochodzą z drugiej połowy XIV wieku (z lat 1370-1380). Zostały one prawdopodobnie zakupione przez siostrę Kazimierza Wielkiego, Elżbietę, dla kościoła klarysek pod wezwaniem św. Andrzeja w Krakowie. Nie są to jednak jeszcze wytwory rodzimego rzemiosła, ale import z warsztatów Nadrenii (por. Historia sztuki polskiej, t. 1, Sztuka średniowieczna, red. T. Dobrowolski, W. Tatarkiewicz, wyd. 2 przejrz. i uzup., Kraków 1965, s. 311; T. Seweryn, Tradycje i zwyczaje krakowskie, Kraków 1961, s. 89-96).
} 
kowane na przełomie XVI i XVII wieku we Włoszech przez tzw. pontanistów², stosunkowo szybko zostały przeszczepione na polski grunt, gdzie znalazły licznych naśladowców, m.in. takich jak: Stanisław Grochowski, Kasper Twardowski czy Kasper Miaskowski, a także wielu innych nieznanych z nazwiska kontynuatorów, wprowadzających do poważnych pieśni kościelnych, opartych na przekazach ewangelicznych, nowe świeckie wątki zaczerpnięte z literatury apokryficznej i tradycji ludowych ${ }^{3}$.

Momentem przełomowym w dziejach polskiej kolędy stało się wydanie w roku 1630 Symfonii anielskich Jana Żabczyca, zbioru liczącego zaledwie 36 tekstów o tematyce bożonarodzeniowej, eksponujących wątek pasterski, którym przypisano melodie popularnych $\mathrm{w}$ tym okresie świeckich pieśni należących do nurtu szlachecko-mieszczańskiego ${ }^{4}$. Wydane teksty stały się pierwowzorem i inspiracją dla wielu bardziej i mniej oryginalnych późniejszych polskich twórców. Z czasem ten nowy nurt rodzimej kolędy, nazwanej pastorałką, zyskał wielką popularność, zarówno wśród twórców, jak i wśród odbiorców, o czym świadczy bogactwo zachowanych zbiorów kolędowych, obejmujących niekiedy kilkaset tekstów, zróżnicowanych gatunkowo i formalnie. Jednym z najobszerniejszych tego typu zabytków są Kantyczki karmelitańskie z XVII i XVIII wieku, wydane przez Barbarę Krzyżaniak ${ }^{5}$. Obejmują one 357 utworów, reprezentujących różne nurty oryginalnej polskiej twórczo-

${ }^{2}$ Nowatorstwo pomysłu Jakuba Pontana (1542-1626), włoskiego jezuity, autora zbioru Floridorum libri octo (1595), polegało głównie na ukazaniu narodzenia i wczesnych lat dziecięcych Jezusa w sposób bardzo realistyczny i ludzki. Przyszły Zbawca świata przedstawiony jest jako słabe i bezbronne niemowlę potrzebujące troskliwej matczynej opieki. Ten sposób patrzenia na rzeczywistość betlejemską burzył powszechnie przyjęta, utrwaloną we wcześniejszych zabytkach tradycyjną konwencję literacką, nakazującą przedstawianie Chrystusa w całym majestacie władcy czy surowości najwyższego sędziego.

${ }^{3}$ Por. M. Borejszo, Geneza i dzieje polskich kolęd, w: Boże Narodzenie w polskiej kulturze, Poznań 1996, s. 53-84.

${ }^{4}$ Por. J. Krzyżanowski, U kolebki pastoratek, w: Paralele. Studia porównawcze z pogranicza literatury i folkloru, Warszawa 1977, s. 320-327.

${ }^{5}$ Zob. Kantyczki karmelitańskie. Rękopis z XVIII wieku, przygotowała do wydania B. Krzyżaniak, Kraków 1980, ss. 419. Udokumentowany w rękopisach karmelitańskich zbiór pieśni kolędowych powstawał stopniowo, od połowy XVI do końca XVIII wieku. Na użytek klasztorny zaczęto go jednak spisywać prawdopodobnie dopiero w pierwszych dziesięcioleciach XVIII wieku i pracę tę kontynuowano do końca stulecia, na co wskazuje odnotowanie w omawianym zbiorze kolędy Franciszka Karpińskiego Bóg się rodzi, wydanej w Supraślu w roku 1792, a rok później w Wilnie (zob. ibidem, s. 365-400). W wykorzystanym zbiorze zdecydowaną przewagę liczebną mają utwory z okresu baroku. Z wydań obejmujących kolędy wieków wcześniejszych, to jest średniowiecza i renesansu, w tym miejscu warto odnotować obszerną, starannie wydaną antologię Kolędy polskie. Średniowiecze i wiek XVI, red. J. Nowak-Dłużewski, t. 1-2, Warszawa 1966. 
ści bożonarodzeniowej ${ }^{6}$. Teksty te (niekiedy wraz z melodiami) ${ }^{7}$ spisywano na użytek klasztoru sióstr karmelitanek w Krakowie ${ }^{8}$. Są to przede wszystkim utwory oryginalne, rodzime, ale także tłumaczenia oraz sporadycznie kolędy obce, np. łacińskie, słowackie, ruskie ${ }^{9}$. Monografię zabytku opracowała Barbara Krzyżaniak, głównie pod kątem muzykologicznym ${ }^{10}$. Omawiany zbiór pieśni kolędowych interesował jednak również badaczy innych specjalności, np. historyków literatury i folkloru, w mniejszym stopniu językoznawców ${ }^{11}$.

Celem mojej pracy jest, jak wynika z tytułu, prezentacja świata ptaków, udokumentowanego w badanym zbiorze twórczości kolędowej ${ }^{12}$. Zasób leksemów, tworzących badane pole, jest dość liczny, bo reprezentowany przez kilkadziesiąt gatunków, głównie rodzimych, ale także niekiedy egzotycznych

${ }^{6}$ Rzeczywista liczba kolęd zamieszczonych w rękopisie karmelitańskim przechowywanym w zbiorach Biblioteki Głównej Uniwersytetu im. A. Mickiewicza w Poznaniu, który stanowi podstawę wydania przygotowanego przez Barbarę Krzyżaniak, nie pokrywa się z ich numeracją (ostatnia zapisana w zabytku kolęda ma numer 378). Przyczyną tego są uszkodzenia rękopisu, brak niektórych stron oraz pomyłki skryptorów w numeracji kolejnych pieśni (zob. Kantyczki karmelitańskie..., s. 365).

${ }^{7}$ Melodii jest tu jednak bardzo niewiele w stosunku do liczby zapisanych tekstów kolędowych, bo zaledwie 78. Zob. ibidem, s. 365 .

${ }^{8}$ Zachowane rękopisy karmelitańskie z czasem uległy rozproszeniu i obecnie są one w posiadaniu Biblioteki Jagiellońskiej, klasztoru karmelitanek w Krakowie i Biblioteki Głównej Uniwersytetu im. A. Mickiewicza w Poznaniu. Zob. ibidem, s. 365.

${ }^{9}$ Por. np. kolędy o numerach: 179 (rus.), 217a (łac.), 258 (słowac.).

10 Jest to monografia historycznoliteracka i etnograficzno-muzykologiczna. Kilka lat po jej opublikowaniu ta sama autorka wydała również pełny tekst wykorzystanego w monografii rękopisu. Zob. B. Krzyżaniak, Kantyczki z rękopisów karmelitańskich (XVII/XVIII w.), Kraków 1977, ss. 227; Kantyczki karmelitańskie...

${ }^{11}$ Por. np.: A. Chybiński, Zbiór kolęd polskich z roku 1721, „Słowo Polskie” 1922, nr 300, s. 10; M. Bokszczanin, Kantyczka Chybińskiego. Z tradycji biblijnych i literackich kolędy barokowej, w: Literatura. Komparatystyka. Folklor. Księga poświęcona Julianowi Krzyżanowskie$m u$, red. M. Bokszczanin, S. Frybes, E. Jankowski, Warszawa 1968, s. 712-791; J. Godyń, Język intymny w kolędach polskich z XVIII wieku, „Język Polski” 1994, z. 1, s. 1-13; idem, Folklor i gwara w pastoratkach karmelitańskich z XVIII wieku, w: Z kolęda przez wieki. Kolędy w Polsce $i$ w krajach stowiańskich, red. T. Budrewicz, S. Koziara, J. Okoń, Tarnów 1996, s. 263-271; M. Borejszo, Antroponimy w kolędach polskich XVII i XVIII wieku, „Poradnik Językowy” 2008, z. 10, s. 85-97; eadem, Obraz świętego Józefa w kolędach polskich XVII i XVIII wieku (na materiale tzw. ,Kantyczek karmelitańskich”), „Poradnik Językowy” 2010, z. 2, s. 5-16; eadem, Obraz Maryi w kolędach polskich XVII i XVIII wieku (na materiale tzw. „Kantyczek karmelitańskich”), „Slavia Occidentalis” 67, 2010, s. 11-20.

${ }^{12}$ O świecie zwierzęcym w kolędach pisał wcześniej Stanisław Koziara, traktując temat bardzo szeroko, tzn. w całych dziejach polszczyzny, od średniowiecza po czasy najnowsze. W związku z tak szerokim ujęciem problemu interesujące nas tutaj zagadnienie zostało potraktowane przez autora bardzo skrótowo. Zob. S. Koziara, Świat zwierzęcy w kolędach, w: Z kolęda przez wieki. Kolędy w Polsce i w krajach stowiańskich, red. T. Budrewicz, S. Koziara, J. Okoń, Tarnów 1996, s. 233-245. 
na ziemiach polskich. Wzmianki o ptakach pojawiają się w ponad 30 tekstach kolędowych na 357 tam zgromadzonych, czyli w niemal 9\% utworów, przy czym szczególne nagromadzenie interesującego mnie materiału występuje w kilku pieśniach, wykorzystujących głównie motyw ptasiej radości z powodu narodzin dawno oczekiwanego Mesjasza ${ }^{13}$.

Świat ptasi wykorzystywany jest w kolędach w różnych celach, np. w opisach nędznej szopy betlejemskiej, w której nie tylko hula wiatr, ale również gnieździ się pod słomianą strzechą drobne ptactwo (m.in. wróble) ${ }^{14}$, przy wyrażaniu żalu z powodu bezdomności Jezusa, w sytuacji gdy nawet ptaki mają swoje bezpieczne i ciepłe gniazda, a przyszły Zbawiciel świata i jego najbliżsi są skazani na tułaczkę i bezdomność ${ }^{15}$, przy okazji wymieniania darów składanych Jezusowi przez pasterzy (jest to wówczas głównie ptactwo domowe: kury, gęsi, indyki, kaczki) ${ }^{16}$, w relacji z podróży Rodziny Świętej do Egiptu ${ }^{17}$. Ptaki mogą też pełnić przy żłobku Dzieciątka różne funkcje służebne, np. łapią latające w szopie muszki (sikorki) czy łowią myszy (sowy) ${ }^{18}$ lub po prostu wyrażają swą radość śpiewem, bawią i rozweselają małego Jezusa ${ }^{19}$.

Udokumentowane w kolędach ptaki, zgodnie z sugestią jednego z anonimowych autorów pieśni (267), reprezentują kilka zbiorów. Jest to ptactwo leśne, lotne, wodne i domowe. Niekwestionowanym królem ptaków jest oczywiście orzel (267). Z przedstawicieli innych gatunków, bardziej lub mniej znanych na ziemiach polskich, pojawiają się tam jeszcze: bażant (267), bąk ${ }^{20}(177$, 267), bocian (177, 267), chrzuściciel 'chruściel'21 (267), ciećwierz 'cietrzew' (267), cyranka (267), czajka (267, 293), czapla (267), czeczotka (267), czyżyk (267), drozd (153), dudek (177, 267), dzierlatka (267), dzięcioł (171), gawron $(177,267)$, gęś $(267,270,333)$, gil (171), gołąb (267), indyk (267,

13 Największe nagromadzenie informacji o ptakach pojawia się w pieśniach o numerach: 153 (Kapela powietrzna), 177 (Kolenda wieyska), 267 (Pieśn o weselacym się ptastwie z narodzenia bozego na godach), 293 (Pieśń). W dalszej części artykułu przy odwołaniach do tekstów poszczególnych kolęd będę podawała jedynie ich numery w rękopisie i opublikowanej antologii, a nie tytuły, ponieważ nie wszystkie pieśni zostały nimi opatrzone.

14 Por. $315,323$.

15 Por. 52, 69, 74, 133, 323.

16 Por. 112, 127, 132, 136, 138, 242, 257, 270, 271, 279, 309, 333, 335.

17 Por. 171.

18 Por. 112.

19 Por. 153, 241, 267, 293.

${ }^{20}$ Bak 'ptak o gliniastobrązowym, pstrym upierzeniu, wydający donośny, buczący głos, żyjący w szuwarach Eurazji i północnej Afryki’. Uniwersalny słownik języka polskiego, red. S. Dubisz, t. 1, Warszawa 2003, s. 212. Zob. też: Kantyczki karmelitańskie..., s. 401.

${ }^{21}$ Chruściel 'ptak z rodziny Rallidae (z rzędu żurawiowatych) obejmującej liczne gatunki, zamieszkujące błota, trzciny, zarośla i stepy; in. derkacz’. Słownik języka polskiego, red. W. Doroszewski, t. 1, Warszawa 1958, s. 918. 
270, 279), jarząbek (267), jastrząb (267), kaczka (267), kania (267), kawka (171), kos (177, 242, 267), kruk (177, 267), kukawka 'kukułka' (171), kura (242, 333), kuropatwa (267), kwiczol (267), labędź (177), makolągwa (153), mazurek $^{22}$ (293), paw (267), przepiórka (267), puchacz (267), raróg (267), sęp (267), sikora (177), skowronek $(177,241,267,305)$, słowik (153, 171, 267, 293, 305), sokół (267), sowa (177, 241, 267, 270), sójka (267), sroka (177, 267, 293), struś (267), szczygiel (171, 267, 293), szpak (293), trznadel (267), wilga (267), wrona $(177,267)$, wróbel $(177,241,267,293,315)$, zięba (267), żołna (267), żuraw $(177,267,293)$. Z ptaków egzotycznych na ziemiach polskich pojawiają się tylko dwa gatunki: kanarek $(171,267)$ i papuga $(267)$. W sumie różnych gatunków ptactwa zostało udokumentowanych w badanym zbiorze kolęd około 60, natomiast nazw ptaków mamy nieco więcej, ponieważ część wyrazów to odrębne określenia samców i samic, a także nazwy młodych ptaków, nazwy bliskoznaczne, wyspecjalizowane oraz gwarowe, np.: gasior (177, 267), kaczor (177, 242, 267, 270), kapłon (270), kogut (138), kur (267, 293), kurczę (133, 267, 270), kacka 'kaczka' (270), kokos 'kokosz' (333). Dość rozbudowana jest tu również grupa spieszczeń, sygnalizujących z reguły pozytywny stosunek autorów czy bohaterów kolęd (głównie pasterzy) do tego fragmentu świata przyrody, np.: czyżyczek (171), gaska (242, 279, 309), gotąbeczek (257), gołabek (293), kukaweczka (171), kurczatko (271, 279, 335), kurka (132, 138), papużeczka (125), sikoreczka (112), sówka (112), szczygiełek (153), wróblatko $(323)^{23}$.

Jak wynika z obserwacji, informacje dotyczące ptaków nie ograniczają się jedynie do podania ich nazw. Autorzy kolęd wykazują dobrą orientację m.in. w takich sprawach, jak: charakterystyczne cechy fizyczne poszczególnych gatunków (np. wielkość, kolorystyka i rodzaj upierzenia, kształt dzioba, długość szyi, wielkość ogona, mały lub duży otwór przełyku, głos wydawany przez ptaki), upodobania dotyczące miejsc, w których gnieżdżą się lub przebywają poszczególne gatunki ptaków, sposobów ich przemieszczania się w przestrzeni, typowych zachowań itp. Do małych ptaków zaliczono np. czeczotkę, czyżyka, kanarka, szczygła, trznadla i ziębę $(171,267)$. Z innych charakterystycznych ptasich cech w tekstach kolęd odnotowano: upierzenie gila, które wyróżnia się bogatą kolorystyką (171), upstrzone upierzenie dzięcioła (171), purpurowy kapturek i szyję mieniącą się kolorem zielono-czarno-błękitnym (jak szyja kaczora) u szczygła (171): Gil się z kolorem swoim popisowat,/

${ }^{22}$ Mazurek 'ptak nieco mniejszy od wróbla, o szarobrązowym upierzeniu, na główce cynamonowym, po bokach dzioba - białym z czarnymi plamkami, żyjący w Eurazji z dala od osiedli ludzkich'. Słownik języka polskiego, red. S. Dubisz, t. 2, Warszawa 2003, s. 590.

${ }^{23} \mathrm{~W}$ niektórych wypadkach w grę może wchodzić także stylizacja na potoczną lub gwarową odmianę polszczyzny bądź określanie osobników niedorosłych, młodych. 
ale go dzięciot upstrzony celowat,/ szczygiet w kapturek przybrat purpurowy/ główkę, przydawszy maści kaczorowej/ do szyje, do szyje (171).

Jeżeli chodzi o inne szczególne cechy ptasiego wizerunku odnotowane przez autorów badanego zbioru kolęd, to np. długim dziobem (nazywanym nosem) charakteryzują się bocian, dudek i żuraw: A jeźli będzie [wino - M.B.] $w$ dzbanie,/ pożycz nam nosa bocianie (267); dudek z wielkim nosem/ zwotywat ich [leśne ptactwo - M.B.] glosem/ na gody (267); A żórawie w swoje nosy/ wykrzykuja pod niebiosy (293). Żuraw, oprócz okazałego dzioba, ma także dhugą szyję: żóraw dtugiej szyje/ rad tė̇ dobrze pije [wino z dzbana - M.B.] (267), natomiast wielkim, efektownym ogonem może poszczycić się paw: Paw ogon śliczny roztoczyt (267). Bąka wyróżnia wśród ptaków szeroki, pojemny przełyk (gardziel), a kanarka - odwrotnie - mały otwór gębowy: A co nadzbyt [wina - M.B.] będziem miaty, / u baka gardziel niemaly,/ więc go pożyczemy,/ do domu weźmiemy/ ostatek (267); Szczygiet z czyżkiem i z zięba,/ i kanarek z mała gęba,/ trznadle z czeczotkami/ były szczebiotkami/ wzajemnie (267).

Autorzy kolęd odnotowują również, choć dzieje się to zupełnie sporadycznie, upodobania poszczególnych gatunków ptaków do określonych pokarmów, np. czapli, sów czy wróbli: Koty wszystkie powysyłat [kur - M.B.],/ aby przynieśli specyjat/ dla czaple i sowy,/ kotom bardzo zdrowy/ jak myszy, tak szczury./ Wróblom zaś kazal domowym/ do gumna poka[za]t owym,/ co zboże jadaja,/ choć w lesie siadaja/ na drzewie (267).

Znacznie więcej uwag dotyczy rozmaitych ptasich upodobań, trafnie zaobserwowanych przez ludzi żyjących na co dzień w bliskim kontakcie z przyroda. $Z$ tekstów kolędowych można dowiedzieć się, że ptaki mają swoje gniazda w krzakach: gniazda/ w krzakach maja wygodne ptasęta (270); kur (czyli kogut) przesiaduje na grzędzie lub siedzi pod strzechą i stamtąd donośnie pieje: Kur na grzędzie krzyczy wszędzie,/ Bóg w ciele lud zbawiać będzie (293); sam zaś wlazt [kur - M.B.] pod strzechę,/ by mieli [goście - M.B.] uciechę,/ przyśpiewat (267); gąsior prowadzi lecące stado gęsi: Gęsiom się wiedzieć dostato, / ze tam ptastwo poleciato, / gasior ich zwiódt pasmo,/ by nie byto ciasno/ w Betlejem (267); sowy i puchacze, nocne ptaki, chętnie kryją się w szopach i stodołach: Sowy, puchacze,/ nocni surmacze,/ którzy się w szopach kochacie,/ Jezusa dziś w szopie macie (153); Sowa tamże mocno huka, / a wróblów w stodole szuka $(241)^{24}$; wróble siedzą zwykle w lesie na drzewach $(267)^{25}$; skowronki śpiewają wysoko w górze: Śpiewaj skowronku,/ niebieski dzwonku,/ ku

${ }^{24} \mathrm{~W}$ jednej z kolęd odnotowano także to, że sowa widzi dobrze nie w dzień, lecz w nocy: Sowa nieboga huczała,/ we dnie wina nie widziała, [...] Ale gdy było w pótnocy,/ piła do ciężkiej niemocy (267).

${ }^{25}$ Por. cytat zamieszczony wyżej przy wymienianiu upodobań w zakresie pożywienia. Wróble, prawdopodobnie ze względu na miejsce przebywania, w jednej z kolęd zostały też na- 
górze się podbijając,/ wiosnę miła ogłaszajac (153); słowik ma donośny głos, w związku z czym zagłusza cichy śpiew małego czyżyka: Czyżyczek mały, że go słowik głuszyt,/ mniemajac, że się Panu nie przystużyt,/ przyleciat $i$ siadt na ucho osłowi (171); mazurek upodobał sobie miejsce za kominem: A mazurek z swoim synem/ tak świergocze za kominem,/ cierp, cierp, cierp, cierp mity Panie,/ póki ten mróz nie ustanie (293); cyranki zwykle latają stadem: Stadem cyranki leciały (267); jastrząb, polując, szarpie pazurami swoją zdobycz: A jeźli nie wypijecie [wina - M.B.],/ jastrzębia poczęstujecie,/ by was pazurami,/ latajac za wami,/ nie szarpał (267); kos pięknie śpiewa, można go też nauczyć powtarzania określonych melodii: Zaśpiewaj kosie/ na brzmiacym nosie,/ niech się twój kornet ozowie,/ Jezusa światu opowie (153); uczone kosy śpiewaty (267); szpaki i papugi to ptaki, które można nauczyć powtarzania pojedynczych słów czy nawet prostych zdań: Papugi, szpacy,/ wymowni ptacy,/ dobadźcie dziś swej wymowy,/ mówcie: witaj Królu nowy (153); Papuga także gwarzyła,/ coś z cudzoziemska mówiła (267) ${ }^{26}$; kanarka można nauczyć pięknego śpiewu: Kanarek rytmy śpiewał nauczone,/ cudownie słowa wyrażat złożone,/ że to Bóg, światu wszystkiemu ogłaszat, a coraz wiwat! Wesoło powtarzat (171).

Zachowania niektórych przedstawicieli ptasiego gatunku zostały też czasami dokładniej opisane w kolędach. Takiego opisu doczekała się na przykład kukułka (kukawka): Wtem się ozwała kukaweczka blisko/ i zakukała, jakoby igrzysko/ czyniac z ptaszęty; wrzkomo sie im kryła/ a coraz ku ku do siebie wabiła (171).

Bardzo chętnie autorzy kolęd wspominają również o charakterystycznych ptasich głosach: gołąb grucha $(267,293)$, kaczka kwacze (267), kogut albo kur pieje (171, 267), kos uczony śpiewa (267), kukawka (kukułka) kuka ${ }^{27}$ (153, 171), kwiczoł kwiczy (267), papuga mówi z cudzoziemska (267), mazurek świergocze (293), puchacz pucha (267), sowa huka $(241,267)$ albo kwicy ${ }^{28}$ (270), sójka huka (267), wrona kracze (267), wróbel czerka 'ćwierka' (153) albo świergocze (315). Niekiedy ptasie głosy określane są także za pomocą onomatopei, np.: cierp, cierp $(241,315)$ lub dziw, dziw (293) to głos wydawany przez wróble, cierp, cierp (241) to również głos mazurka, sowa woła $h u, h u$

zwane kościelnymi stróżami: Czerkajcie wróblowie,/ kościelni stróżowie,/ Panu Bogu swojemu/ dzisiaj zrodzonemu (153).

${ }^{26} \mathrm{~W}$ jednej z kolęd małego Jezusa, rozbawionego przez pasterzy, przyrównuje się do papużki, powtarzającej za nimi słowa piosenki: Wzięła się [Dziecineczka - M.B.] za boczki, tup tup nóżkami,/ jako papużeczka śpiewała z nami:/ lala lala la Michale,/lala lala la Iwanie,/ lu lu lu lu (125).

27 Przy okazji dowiadujemy się także, że kukanie kukułki słychać w maju (153).

${ }^{28} \mathrm{~W}$ ten sposób głos sowy określa jeden z pasterzy mówiący gwarą (mazurząca). 
(267) lub pódź, pódź (241), kukułka ku, ku (171), a wrona krak (267). Jeden $\mathrm{z}$ autorów kolęd scharakteryzował też negatywnie głos wydawany przez pawia, nie opisując go jednak dokładniej: Paw ogon śliczny roztoczyt, / lecz sprosznym wrzaskiem wykroczyt (267). Jak widać, większość tego typu określeń jest stosowana w polszczyźnie do czasów współczesnych. Mnogość nazw o charakterze onomatopeicznym wskazuje na to, że ptaki nie są w kolędach jedynie niemymi świadkami narodzin Jezusa, jak wół, osioł czy owce, lecz tworzą bardzo hałaśliwą i radosną gromadę gości odwiedzających betlejemską szopę.

W największej liczbie pieśni kolędowych ptactwo (najczęściej domowe) występuje w charakterze darów składanych przez ubogich pasterzy nowo narodzonemu Jezusowi lub całej Rodzinie Świętej. Są to głównie kury, kaczki, gęsi, indyki, ale czasem też inne ptaki (np. kos, gołąb) lub ptasie jaja: wszak masz i kura (127); Ucieszę Pana,/ dam mu barana [...] i kurkę (132); oddajmy mu to weseli/i którq kurę (136); jemu dary pasterze daruja,/jajka, kurki, strucle ofiaruja (138); Bartosz wziat gaskę,/ [...] Michat kur parę wrazit w kobielę, [...] Walaszek z sobq wziat byt kaczora,/ [...] Stach wziat kosa (242); Sobek [przyniósł - M.B.] parę golabeczków małych, ale w pierzu,/ wziat Tomek gomótek i jajeczko gęsie (257); to ja na ofiarę/ kaptonów mu paręl tlustych zaniosę./ [...] Ja gęsi kilkoro,/ ku temu sześcioro/ dam kurczat młodych./ Maciek mu też da indyków/z parę,/Tomek kackę i kaczora [...]/ Franek na ostatek/ wabiów ${ }^{29}$ kilka klatek/daruje Panu (270); a co macie, to dajcie,/ masto, kukle, kurczatka/ dla małego Dzieciatka (271); a ty Marku łysy weź swoja gaskę/ [...] Symek mówi: mam kurczatko, [...]/ [karbowy - M.B.] porwawszy indyka, za nimi bieży (279); wziat [Walaszek - M.B.] gaske w powaske, uwiqzat u pasa (309); Noście kury, kokosy,/ on was z piekta wyptoszy,/ bo tam źle./ Dawajciez mu i gęsi,/ wszak sie wam nic nie umniejszy (333); a ty Marcinie/ idź po drabinie,/ dostań mu kurczatko (335).

Ludzie składają małemu Jezusowi materialne bądź duchowe dary, a ptaki, które takich możliwości nie mają, ofiarują mu na przykład swoją posługę w różnych codziennych czynnościach lub po prostu bawią go i rozweselaja swym śpiewem: Sq dwie sikoreczki chciwe na muszeczki,/ które w stajence dokoła lataja,/muszki, robaczki najmniejsze tapaja./ Sówka na nich [na myszy - M.B.] czuje, sowa ich pilnuje, /jużem ten urzqd sówce poleciła,/żeby stqd wszystkie myszki wyłowita (112); kogut Dzieciateczku pieje (138); skowronek go [Jezusa - M.B.] uwesela/ i dodaje mu wesela (241).

W kilku kolędach ptasi koncert, wyrażający radość z powodu narodzin Zbawiciela, doczekał się nawet bardzo rozbudowanego i szczegółowego opisu $(153,177,267,293)$. Na przykład jedna z pieśni, nosząca tytuł Kapela

${ }^{29}$ Wab 'ptak wystawiony jako przynęta na inne ptaki'. Kantyczki karmelitańskie..., s. 407. 
powietrzna (153), zachęca kolejno poszczególne gatunki ptaków, by swym śpiewem uczciły to niezwykłe w dziejach ludzkości wydarzenie ${ }^{30}$, z innej dowiadujemy się już dokładniej, jak wygląda ten radosny koncert: $W$ dzień Bożego Narodzenia/ radość wszystkiego stworzenia,/ ptaszki się w szopę zlatuja,/ Jezusowi przyśpiewuja./ Stowik zaczyna dyszkantem,/ szczygiet mu pomaga altem,/ szpak tenorem krzyknie czasem,/ a gołabek gruchnie basem./ Wróbel, ptaszek nieboraczek,/ uziabtszy, śpiewa jak żaczek,/ dziw dziw dziw dziw dziw nad dziwy,/ Bóg i człowiek wraz prawdziwy./ A mazurek z swoim synem/ tak świergocze za kominem,/ cierp, cierp, cierp, cierp mity Panie,/ póki ten mróz nie ustanie./ A żórawie w swoje nosy/ wykrzykuja pod niebiosy,/czajka w górę podlatuje,/ chwałe Bogu wyśpiewuje./ Sroka wlaztszy na jedlinę,/ odarła sobie tysinę/ i choć gołe świeci czoło,/ Dzieciatku nuci wesoło./ Kur na grzędzie krzyczy wszędzie,/ Bóg w ciele lud zbawiać będzie (293).

Niekiedy też ptakom przypisuje się w kolędach cechy ludzkie i w tym świecie na opak stają się one muzykami w jakiejś wyimaginowanej orkiestrze, grającymi na różnych instrumentach muzycznych: Ej leluja, ptacy té̇ wspomnieli,/ co przedtem umieli, ej leluja./ Ej leluja, już fraktem śpiewaja./ na muzyce graja, ej leluja./ Ej leluja, skowronek dyszkantem,/ a sikora altem, ej leluja./ Ej leluja, zaś wróbel tenorem,/ a gawron kantorem, ej leluja./ Ej leluja, żóraw organista,/ a bocian lutnista, ej leluja./ Ej leluja, sroka gra w cymbaby,/ a wrona w rygaty, ej leluja./ Ej leluja, skrzypki kos obraca,/ lutnia kruk nakraca, ej leluja./ Ej leluja, na wijoli kaczor,/ na kornecie gasior, ej leluja./ Ej leluja, bak dudy nadyma,/ sowa puzan trzyma, ej leluja./ Ej leluja, dudek w szałamaje,/ łabędź takt podaje, ej leluja. (177); Na muzyce nie schodziło,/ pokazał każdy swe dzieło,/ grat raróg na rogu,/ [...] Kurczęta w piszczatki grały,/ uczone kosy śpiewaty,/ [...] Puchacz swoim głosem puchat,/ a gołab Dzieciatku gruchat,/ wrona krak krakała,/ Boga wyznawała/ na szopie./ A stowik śpiewat dyszkantem,/ a kanarki, skowronki altem,/ a kruk śpiewał basem,/ gawron byt podczasym/ ochotnym (267).

Ptaki, nie tylko tworząc kapelę, wchodzą w ludzkie role, ale także organizując się w szopie, zaczynają pełnić funkcje przypisane ludziom, np. orzel, jako król ptaków, wprowadza do rozkrzyczanej gromady ład: Więc orzeł między ptakami,/lew zaś między zwierzętami/ uczynit porzadek,/ by każdy za wziatek/ co zrobit (267); kogut (kur) pełni w tym zgromadzeniu funkcje gospodarza domu i wyznacza zadania pozostałym ptakom, a nawet innym zwierzętom: Kur jako gospodarz w domu,/ wiedzac co rozkazać komu,/ kazał mało gadać,/

${ }^{30}$ Kapela powietrzna (153), czyli ptasia, występuje łącznie z innymi kapelami, to jest: Kongregacya kapel rozmaitych do szopki betleemskiey dla exhilaracyey Dzieciatka Pana Jezusa (151), Kapela niebieska (152), Kapela uniwersalna (154), Kapela partykularna (155), Kapela generalna (157), Kapela pospolita (158) oraz Kapela cichq naywdzięcznieysza (160). 
a owocu dawać/ dostatek./ [...] Koty wszystkie powysyłat,/ aby przynieśli specyjat/ dla czaple i sowy,/ kotom bardzo zdrowy/ jak myszy, tak szczury./ Wróblom zaś kazat domowym/do gumna poka[za]t owym,/ co zboże jadaja./ choć w lesie siadaja/ na drzewie./ Psom kazat, aby szczekali,/ żeby goście nazdali,/ sam zaś wlazł pod strzechę,/ by mieli uciechę,/ przyśpiewat (267); bażant jest szafarzem, gawron podczaszym, kaczor piwnicznym, natomiast indyk i żolna są syndykami: Gdy przyleciały do dwora [kaczki - M.B.],/ piwnicznym miały kaczora,/lecz mu na te gody/kazały pić wody/ piwnicznym./ [...] gawron byt podczasym/ ochotnym./ [...] żolna i z indykiem/ byta tam syndykiem,/ bazant byt szafarzem (267).

W opisywanym zgromadzeniu ptaki piją też z upodobaniem, podobnie jak ludzie, wino czy piwo z okazji godów: Ptastwo się też dowiedziało,/ za królem swoim leciało/ na królewskie gody,/ nie pili tam wody,/lecz wino./ [...] A gdy kania dżdzu czekała,/ o tychże godach styszała,/ więc odeszła od wody,/ leciata na gody/do wina./[...] Jeszcze jarzqbek z sokołem/ radzit i z ciećwierzem społem:/ rozmów zaniechajmy,/ na gody biegajmy/do wina./[...] żuraw długiej szyje/ rad też dobrze pije,/ [...] wróble zaś gwarzyty,/ gdy sobie podpity/ [...] Sroka piwa nawarzyła,/ korzec weń chmielu włożyła,/ było dobre piwo,/ piło go co żywo/ na godach./ Sowa nieboga huczała,/ we dnie wina nie widziała,/ hu hu hu hu hu hu, a mało co w brzuchu/ bez wina chudzina./ Ale gdy byto w północy,/ piła do ciężkiej niemocy,/ war piwa wypiła,/ jeszcze się swarzyła/ niecnota (267).

Na zakończenie warto jeszcze wspomnieć, że ptaki pojawiają się również w analizowanym zbiorze kolęd w kilku charakterystycznych frazach, które z czasem stały się w polszczyźnie popularnymi przysłowiami, natomiast w momencie powstawania tekstów mogły być jeszcze używane w znaczeniach dosłownych, a nie przenośnych, np.: kania dżḋu czeka (267), sroka piwa nawarzyta $(267)^{31}$.

Z tropów poetyckich nawiązujących do świata ptaków można wymienić porównania, np.: jako papużeczka [Dziecineczka - M.B.] śpiewała z nami (125); Przylecieli anjołkowie jak ptaszkowie z nieba (152); Sójka tym więcej znać dała,/ gdy jak chłop w lesie hukała (267); sęp siedział jako sęp (267); jak słowika głos Ludwika (305).

Omawiane wyżej teksty kolędowe reprezentują $\mathrm{z}$ reguły nurt plebejski (ludowy) oraz szlachecko-mieszczański. Ich celem było niewątpliwie rozweselenie potencjalnych słuchaczy, m.in. przez ukazanie, do jakiego zamętu do-

${ }^{31}$ Por. Nowa księga przystów i wyrażeń przystowiowych polskich, red. J. Krzyżanowski, t. 2, Warszawa 1970, s. 19-20 (jak kania dżdżu czeka // pragnie i in.), 946-949 (nawarzyć piwa). 
szło na świecie po przyjściu na świat Zbawiciela, gdy każdy - w sposób sobie właściwy - chciał wyrazić swą radość i równocześnie oddać należną chwałę nowo narodzonemu Bogu. Wprowadzenie do tekstów popularnych pieśni kolędowych świata ptaków, typowego dla polskich realiów klimatycznych, nie jest, jak już wspominano, w dziejach polskiej i europejskiej tradycji bożonarodzeniowej zjawiskiem oryginalnym i nowym. Kolędy wpisują się w tym wypadku w nurt literatury apokryficznej, sięgającej swymi korzeniami co najmniej czasów średniowiecza. Oczywiście wykreowany przez ówczesnych twórców epiki i liryki religijnej świat w szczegółach mógł wyglądać nieco inaczej w różnych krajach i okresach, uzależniony był on także od gatunku literackiego, wyrobienia słuchaczy, reprezentowanego przez nich poziomu intelektualnego czy funkcji, jaką miał pełnić ten rodzaj literatury w ówczesnej rzeczywistości. W środowisku zakonnym, dla którego potrzeb spisywano teksty popularnych kolęd lub na którego zamówienie utwory te pisano, nie wszystkie pieśni były wykorzystywane w liturgii kościelnej. Część zachowanego zbioru, zwłaszcza ta o charakterze zdecydowanie bardziej świeckim, dalekim od pierwowzoru, czyli od oryginalnego przekazu ewangelicznego, wykonywana była poza świątynią, jako miejscem kultu religijnego. Jeden z zachowanych rękopisów Kantyczek karmelitańskich, przechowywany w Bibliotece Jagiellońskiej (sygn. BJ 3640), oznacza nawet, które pieśni zaleca się wykonywać w czasie bożonarodzeniowej liturgii mszalnej („w chórze”), a które nadają się już raczej jedynie do refektarza (,do refektarza” i „w refektarzu”) $)^{32}$. „W chórze” wykonywano pieśni na Boże Narodzenie o charakterze głównie religijnym, natomiast „w refektarzu” śpiewano zapewne kolędy jasełkowe, adoracyjne, kołysanki, pastorałki itp., w których dość często wykorzystywanym motywem był między innymi wątek ptasiej radości i darów pasterskich, składanych nowo narodzonemu Dzieciątku i jego najbliższym. Znajomość - wśród słuchaczy i wykonawców kolęd - wykreowanego w tych utworach obrazu świata pozwalała z jednej strony zbliżyć i uzwyczajnić betlejemskie realia, obce polskim odbiorcom, z drugiej zaś, przez przedstawienie świata niejako na opak, to znaczy takiego, w którym dzieją się rzeczy niezwyczajne, cudowne, nadprzyrodzone (177, 267), uzmysłowić im wyjątkowość chwili i opisywanych wydarzeń.

Wprowadzenie do prostych i suchych przekazów ewangelicznych nowych wątków służyło też zapewne budowaniu poczucia wspólnoty zakonnej, lokalnej czy narodowej, bazującej na wspólnocie codziennych doświadczeń życiowych. W warunkach klasztornych, w których bezpośredni kontakt ze światem, z przyrodą bywał często ograniczony wymogami reguł zakonnych, świeckie

\footnotetext{
${ }^{32}$ Por. Kantyczki karmelitańskie..., s. 369.
} 
motywy pozwalały podtrzymać lub na nowo poczuć siłę jedności z tym, co obecne, i z tym, co pozostało na zawsze za murami klasztoru.

Autorzy kolęd na ogół pozostają anonimowi, trudno więc rozstrzygnąć, które z pieśni powstały na użytek klasztoru, które zaś przejęto z ogólnopolskiej tradycji kościelnej, szlacheckiej, mieszczańskiej czy ludowej. Specyficzny, miejscami rubaszny, humor sporej grupy tekstów wchodzących w skład badanego zbioru może wskazywać na twórców bliskich tradycji plebejskiej. Trzeba też jednak brać pod uwagę zamierzoną stylizację na tę odmianę języka i typ literatury, która umożliwiała dotarcie do mniej wyrobionego słuchacza, będącego odbiorcą i użytkownikiem tego typu utworów, z założenia użytkowych, powszechnie znanych i wykorzystywanych w codziennej praktyce okresu bożonarodzeniowego, jeżeli nie w liturgii mszalnej, to w czasie świątecznych spotkań rodzinnych, sąsiedzkich czy klasztornych.

\section{Aneks}

W aneksie zamieszczono teksty wybranych przykładowo kolęd, w których pojawia się najwięcej ptasich motywów (153, 177, 267), a które współcześnie nie są szerzej znane i wykonywane, ani w liturgii kościelnej, ani w powszechnej tradycji ${ }^{33}$. Daje to chociaż ogólną orientację, w jakich kontekstach i w jaki sposób został ukazany interesujący nas świat ptaków w badanych utworach.

\section{Kapelá powietrzná}

Każde stworzenie

śpiewaj swe pienie,

iż się narodził Stworzyciel

a nas grzesznych Odkupiciel,

Odkupiciel.

/ : Śpiewajcie ptaszkowie,

wdzięczni śpiewaczkowie,

Panu Bogu swojemu,

dziś narodzonemu

śpiewajcie : /

Śpiewaj słowiku, wdzięczny muzyku, dobądź swej liry wesołej, śpiewaj wesoło $\mathrm{z}$ anjoły,

$\mathrm{z}$ anjoły.

/ : Śpiewajcie ptaszkowie... : /

Śpiewaj skowronku, niebieski dzwonku, ku górze się podbijając, wiosnę miłą ogłaszając, ogłaszając.

/ : Śpiewajcie ptaszkowie... : /

Zaśpiewaj kosie na brzmiącym nosie, niech się twój kornet ozowie, Jezusa światu opowie,

${ }^{33}$ Wszystkie teksty pochodzą z wydania Kantyczki karmelitańskie..., s. 122-124, 147-149, 229-232. 
opowie.

/ : Śpiewajcie ptaszkowie... : /

Wy czyżykowie

i szczygiełkowie

wesoło mu zaśpiewajcie,

z sobą się dziś przepiewajcie,

przepiewajcie.

/ : Śpiewajcie ptaszkowie... : /

Krzyknijcie zięby,

ruszcie swe gęby,

makolągwy i drozdowie

niechaj się wasz głos ozowie, ozowie.

/ : Śpiewajcie ptaszkowie... : /

Sowy, puchacze, nocni surmacze,

którzy się w szopach kochacie, Jezusa dziś w szopie macie, W szopie macie.

/ : Śpiewajcie ptaszkowie... : /

Papugi, szpacy,

wymowni ptacy,

dobądźcie dziś swej wymowy, mówcie: witaj Królu nowy,

Królu nowy.

/ : Śpiewajcie ptaszkowie... : /

Wykrzyknij kawko,

kukaj kukawko,

nie czekaj maja letnego,

oto masz Pana swojego,

swojego.

/ : Śpiewajcie ptaszkowie... : /

Wszystkie ptaszęta, małe pisklęta,

śpiewajcie Panu swojemu

dzisiaj z Panny zrodzonemu, zrodzonemu.

/ : Czerkajcie wróblowie, kościelni stróżowie,
Panu Bogu swojemu

dzisiaj zrodzonemu,

śpiewajcie : /

Małe dziateczki, ziemskie kwiateczki, śpiewajcie z Panny Dziecięciu, nieba i ziemie Panięciu,

Panięciu.

/ : Śpiewajcie mężowie, śpiewajcie starcowie, Panu Bogu Wiecznemu w Trójcy Jedynemu, Jedynemu : /

\section{Kolendá wieyska}

Ej leluja, weselcie się ludzie, już wam dobrze będzie, ej leluja. Ej leluja, Bóg zwalczył szatana, co zdradził Adama, ej leluja.

Ej leluja, ty piekielny smoku, koniec ci w tym roku, ej leluja. Ej leluja, już ci łeb zdeptano, jako obiecano, ej leluja.

Ej leluja, już tu nic nie sprawisz, darmo się tu bawisz, ej leluja. Ej leluja, już to tu, nie w raju, w onym pięknym gaju, ej leluja. Ej leluja, gdzieś nas dla zazdrości pozbawił radości, ej leluja.

Ej leluja, co Ewa straciła, Panna naprawiła, ej leluja. Ej leluja, porodziła Syna, dziwna to nowina, ej leluja. Ej leluja, anjeli śpiewaja, pokój powiadają ej leluja. Ej leluja, na ziemi wesele, że Bóg żyje w ciele, ej leluja. Ej leluja, wszystko się zmieniło co nigdy nie było, ej leluja. Ej leluja, rzeką wino ciecze, ciepło jakby lecie, ej leluja. Ej leluja, lwami drzewo woża, niedźwiedziami orzą, ej leluja. 
Ej leluja, zając z chartem siedza, z jednej miski jedza, ej leluja. Ej leluja, liszka pasie kury, kot myszy i szczury, ej leluja. Ej leluja, wilk owcom nie szkodzi, wespół z nimi chodzi, ej leluja. Ej leluja, ptacy też wspomnieli, co przedtem umieli, ej leluja. Ej leluja, już fraktem śpiewaja, na muzyce grają, ej leluja.

Ej leluja, skowronek dyszkantem, a sikora altem, ej leluja.

Ej leluja, zaś wróbel tenorem, a gawron kantorem, ej leluja. Ej leluja, żóraw organista, a bocian lutnista, ej leluja. Ej leluja, sroka gra w cymbały, a wrona w rygały, ej leluja. Ej leluja, skrzypki kos obraca, lutnią kruk nakrąca, ej leluja. Ej leluja, na wijoli kaczor, na kornecie gąsior, ej leluja. Ej leluja, bąk dudy nadyma, sowa puzan trzyma, ej leluja. Ej leluja, dudek w szałamaje, łabędź takt podaje, ej leluja. Ej leluja, i drzewa to znaja, opak owoc daja, ej leluja. Ej leluja, jabłka na dębinie, gruszki na sośninie, ej leluja. Ej leluja, na wierzbinie wiśnie, na jodlinie trześnie, ej leluja. Ej leluja, bez zakwitł figami, jawor rozynkami, ej leluja. Ej leluja, na głogu brzoskwinie, migdał na tarninie, ej leluja. Ej leluja, płynie miód z kloniny, oliwa z brzeziny, ej leluja. Ej leluja, balsam też z lipiny, a mleko z świrkniny, ej leluja. Ej leluja, gruda też grudniowa jak pigułka zdrowa, ej leluja. Ej leluja, lód i śnieg styczniowy, smak ma kanarowy, ej leluja.
Ej leluja, słusznie się radować, a Bogu dziękować, ej leluja. Ej leluja, iż przez narodzenie zmienił przyrodzenie, ej leluja. Ej leluja, a człeka grzesznego wziął za brata swego, ej leluja.

\section{Pieśn o weselacym się} ptastwie z narodzenia Bożego na godach

W dzień Bożego narodzenia radość wszystkiego stworzenia, ptastwo chwali Pana, bydło na kolana / : upada : /.

Król orzeł najprzód przyleciał, gdy się o godach dowiedział, nawiedził Dzieciątko, małe Pacholatko /: w Betlejem :/.

Ptastwo się też dowiedziało, za królem swoim leciało na królewskie gody, nie pili tam wody, / : lecz wino : /.

Którym chcąc zagrzać struś głowę, a do tego zjadł podkowę, by ją prędzej strawił, na gody się stawił, Jezusa Chrystusa.

A gdy kania dżdżu czekała, o tychże godach słyszała, więc odeszła wody, leciała na gody / : do wina :/.

Stadem cyranki leciały, więc kaczki bardzo kwakały, myśliwiec je brokiem 
postraszył aż wskokiem

/: uciekły : /.

Gdy przyleciały do dwora, piwnicznym miały kaczora, lecz mu na te gody kazały pić wody / : piwnicznym : /.

Obchodziło to kaczora i nie chciał czekać wieczora, ale go żórawie strzepały po głowie / : i ucicht :/.

Gęsiom się wiedzieć dostało, że tam ptastwo poleciało, gąsior ich zwiódł pasmo, by nie było ciasno /: w Betlejem :/.

Gdy wodne ptastwo leciało, leśne się też dowiedziało, dudek z wielkim nosem zwoływał ich głosem / : na gody :/.

Sójka tym więcej znać dała, gdy jak chłop w lesie hukała, bo się już upiła, gdy na godach była /: w Betlejem :/.

Szczygieł z czyżykiem i z ziębą, i kanarek z małą gębą, trznadle z czeczotkami były szczebiotkami /: wzajemnie : /.

Darmo na wino pójdziemy, bo go mało wypijemy chrzuściciel i z wilgą dobrą, choć niewielką / : poradą: /.
Mówiąc, za co nam to stanie, gdy się nam widzieć dostanie w Betlejem wesele, które w ludzkim ciele / : Bóg sprawił :/.

Jeszcze jarząbek z sokołem radził i z ciećwierzem społem: rozmów zaniechajmy, na gody biegajmy / : do wina : /.

A jeźli nie wypijecie, jastrzębia poczęstujecie, by was pazurami, latając za wami, / : nie szarpał : /.

Ptastwo się z lasa porwało, bo się im to spodobało, lecąc z kuropatwą, przepiórka tę łatwą / : da radę : /.

A co nadzbyt będziem miały, u bąka gardziel niemały, więc go pożyczemy, do domu weźmiemy / : ostatek :/.

A jeźli będzie w dzbanie, pożycz nam nosa bocianie, żóraw długiej szyje rad też dobrze pije, / : da jej nam : /.

I tak różnych ptasząt stado, będąc Jezusowi rado, w to miejsce leciało, kędy Pańskie ciało /: powito : /.

Spocząć chciały niebożęta, lecz zastąpiły zwierzęta, 
bydlęta, robacy

i domowi ptacy

chwalili Dzieciątko.

Zaczym wszystek dom okryli, gdy się w szopce nie zmiejścili, potem zgodne głosy, wrzaski pod niebiosy

/ : leciały : /.

Chwała bądź Bogu żywemu, ubogo narodzonemu dla człeka nędznego, by kto potu swego / : miał koniec : /.

Podziękowawszy Dzieciątku, każdy się z nich miał do wziątku, Bóg im błogosławił, gdy się na świat zjawił /: w pieluszkach :/.

Dopieroż tam wrzawa była, kiedy było zwierząt siła, żaden nie chciał robić, każdy wolał święcić / : na godach :/.

Więc orzeł między ptakami, lew zaś między zwierzętami uczynił porządek, by każdy za wziątek / : co zrobił :/.

Wprzód uczcili gospodarstwem bydlęta $\mathrm{z}$ domowym ptastwem, by leśne zwierzęta i wodne ptaszęta / : raczyli : /.

Kur jako gospodarz w domu, wiedząc co rozkazać komu, kazał mało gadać, a owocu dawać / : dostatek : /.
Pana obudził swym pianiem, by żyli jego staraniem czeladź, także dziatki, by mieli dostatki

/ : i goście : /.

Koty wszystkie powysyłał, aby przynieśli specyjał dla czaple i sowy, kotom bardzo zdrowy jak myszy, tak szczury.

Wróblom zaś kazał domowym do gumna poka[za]ł owym, co zboże jadają, choć w lesie siadają / : na drzewie :/.

Psom kazał, aby szczekali, żeby się goście nazdali, sam zaś wlazł pod strzechę, by mieli uciechę,

/: przyśpiewał :/.

Na muzyce nie schodziło, pokazał każdy swe dzieło, grał raróg na rogu, słoń dał chwałę Bogu

/: swym nosem : /.

Kurczęta w piszczałki grały, uczone kosy śpiewały, niedźwiedź pacierz mówił, koń zębami dzwonił / : nad żłobem : /.

Puchacz swoim głosem puchał, a gołąb Dzieciątku gruchał, wrona krak krakała, Boga wyznawała / : na szopie :/.

A słowik śpiewał dyszkantem, z kanarki, skowronki altem, a kruk śpiewał basem, 
gawron był podczasym

/: ochotnym :/.

Kozioł się brodą trząsał gdy skórę z drzewa okąsał, Jagnięta beczały, gdy płacz usłyszały Jezusa Chrystusa.

A zaś zając z królikami bębnił swoimi nóżkami, wróble zaś gwarzyły, gdy sobie podpiły $\mathrm{z}$ dzierlatką, z czeczotką.

Papuga także gwarzyła, coś z cudzoziemska mówiła, żołna i z indykiem była tam syndykiem, bażant był szafarzem.

Paw ogon śliczny roztoczył, lecz sprosznym wrzaskiem wykroczył, kwiczoły kwiczały, czeczotki śpiewały, sęp siedział jako sęp.

A jeleniowe zaś czoło na rogach świec mając wkoło, tam wszystkim świeciło, aby widzieć było / : cieszyć się :/.

Wilcy grali w szałamaje, czajka ochoty dodaje, koniki skakały, świercze pomagały / : z mrówkami : /.

Więcej tam było wszystkiego niżeli w arce Noego, tam tylko po parze, a tu zaś co może /: mieć ziemia :/.

Sroka piwa nawarzyła, korzec weń chmielu włożyła, było dobre piwo, piło go co żywo / : na godach :/.

Sowa nieboga huczała, we dnie wina nie widziała, hu hu hu hu hu hu, a mało co w brzuchu bez wina chudzina.

Ale gdy było w północy, piła do ciężkiej niemocy, war piwa wypiła, jeszcze się swarzyła / : niecnota :/.

Jak skoro Boga uczciło, co żywo się rozproszyło, ludziom przykład dawszy, Boga powitawszy, chwalili, chwalili.

Amen. 


\section{Maria Borejszo}

\section{The realm of birds in old-Polish Christmas carols and Christmas festivity songs (based on the material of Kantyczki karmelitańskie [Carmelite canticles] from the seventeenth and the eighteenth centuries)}

The article discusses the image of birds as documented in Kantyczki karmelitańskie [Carmelite canticles] from the $17^{\text {th }}$ and the $18^{\text {th }}$ centuries published by Barbara Krzyżaniak in 1980. Birds are to be found in more than 30 lyrics of Christmas carols (for the total number of 357 contained in the set under scrutiny). These include mainly domestic birds, very well-known both to the authors of the canticles and to the recipients and users of Polish Christmas carols and Christmas festivity songs. In total, about 60 species of birds are specified, including two exotic birds (the canary and the parrot).

The bird's realm was used in Christmas carols for different purposes, e.g. in the descriptions of the Bethlehem shed that is inhabited by petty birds, mentioned on account of the enumeration of gifts given to Jesus by shepherds, in accounts of the Flight to Egypt by the Holy Family, and in descriptions of the joy of the whole of the world of nature at the birth of the Saviour.

It is worth noting that creators of Christmas carols did not limit themselves to just mentioning names of particular species of birds, but also provide a description of characteristics, sometimes a detailed one, such as the appearance and behaviour of its particular representatives. The carols include, for example, information on the habitat of birds, type and colouring of the plumage, common sounds made by various birds, staple food of birds, the shape of the beak and the size of the gullet.

The birds pictured in the Christmas carols were either members of a village band up in the air (some sort of flying band), joyfully proclaiming Good News to the world (a motif often made used of in old-Polish Christmas carols and festive songs), or gathered at the manger to perform menial services and functions in real word reserved only for humans. Birds take on typically human behaviour, show human dispositions and fancies, customs and habits (e.g. wine or beer drinking in the nuptials).

KEY wORDs: Christmas, Christmas carol, song, bird.

prof. dr hab. Maria Borejszo, Pracownia Leksykologii, Instytut Filologii Polskiej Uniwersytetu im. Adama Mickiewicza; podejmowane tematy badawcze: historia języka polskiego, dzieje języka religijnego, język pisarzy, struktura i język wybranych tekstów użytkowych. 